\author{
Bhupendra Kumar KC \\ University of Stavanger \\ Stein Erik Ohna \\ University of Stavanger
}

DOI: http://dx.doi.org/10.5617/adno.7821

\title{
Preservice teachers' reflections on diversity and on teaching diverse pupils in Norwegian compulsory school
}

\begin{abstract}
The purpose of this study is to investigate how preservice teachers reflect on diversity and on teaching pupils from diverse backgrounds. Following a qualitative research design, the empirical data were constructed through focus group interviews with preservice teachers attending a 4-year initial teacher education programme for compulsory school in Norway. The thematic analysis of focus group interviews yielded three main results, namely differences are individual and considered natural, diversity as a value and challenge, and belief in practice rather than theory. Results suggest that despite their appreciative views towards diversity, the preservice teachers seem to be having a dilemmatic position regarding whether they should treat every pupil the same or differently. Moreover, the results point to the significance of establishing coherence between theory and practice in initial teacher education regarding the preparation of preservice teachers for their work with diverse pupils.
\end{abstract}

Keywords: initial teacher education, diverse classrooms, theory-practice coherence

\section{Lærerstudenters refleksjoner over undervisning og mangfold i norsk grunnskole}

\begin{abstract}
Sammendrag
Formålet med denne studien er å undersøke hvordan lærerstudenter i den fireårige grunnskolelærerutdanningen reflekterer over mangfold og undervisning av elever som har ulik bakgrunn. Studien er basert på et kvalitativt forskningsdesign, og data er konstruert ved hjelp av fokusgruppeintervjuer med lærerstudenter i den fireårige grunnskolelærerutdanningen. Den tematiske analysen ledet fram til tre hovedresultater: Forskjeller er individuelle og forstås som noe naturlig, mangfold som en verdi og utfordring, og vektlegging av praksis heller enn teori. Resultatene viser at til tross for deltakernes verdsetting av mangfold, opplever lærerstudentene dilemma når det gjelder hvordan de skal handle i praksis. Resultatene peker videre på betydningen av å etablere koherens mellom praksis og teori i lærerutdanningen for å forberede lærerstudentene for arbeidet med mangfoldige elevgrupper.
\end{abstract}

Nøkkelord: lærerutdanning, mangfold i klasserom, teori-praksis koherens 


\section{Introduction}

Societies around the world have become increasingly diverse, mainly due to the process of globalisation and growing migration both within and across countries (Banks, 2012; Koppelman, 2011). Diversity is a multi-faceted concept and can be understood in many ways. According to Banks (2008), it can be considered in terms of categorical variations, such as ethnicity, religion, culture or other similar attributes associated with human differences. On the other hand, Florian and Pantić (2017) suggest that diversity should be conceptualised as "an integral aspect of humanity rather than a series of categorical distinctions that differentiate and separate individuals and groups" (p. 1). In educational settings, diversity may refer to learners who differ according to ethnicity, gender, religion, culture, language and socio-economic status (Banks, 2008); it can also include the intellectual differences of the learners (Florian et al., 2010). In this study, we take a fairly open approach to diversity, like that conceptualised by Florian and Pantić (2017), who refer to aspects of understanding human differences that characterise both individuals and groups from multiple perspectives.

The growing diversity in society has implications for education (Florian \& Pantić, 2017). The diversification of pupils has, for example, ramifications for teachers' work in classrooms and generates additional professional challenges concerning how teachers can ensure that all pupils have the same opportunities regardless of their differences (Humphrey et al., 2006). Broadly speaking, the purpose of education is to prepare individuals to live in a society that is committed to plurality and difference (Biesta, 2006), and teachers are key acting agents in achieving this goal. Since teachers play such an important role in responding to the varied needs of diverse learners, initial teacher education (ITE) can perform a vital function in preparing teachers to address the needs and challenges associated with diversity. Therefore, a well organised ITE fills an important position in the preparation of prospective teachers for working in classrooms characterised by diverse student populations (Tyson \& Ball, 2011; OECD, 2010).

\section{The Norwegian context}

Norwegian society has undergone significant transformations with respect to its immigrant population in recent years. For instance, in 2000, 6.3\% of Norway's population had an immigrant background. By 2020, this figure has increased to 18.2\% (Statistics Norway, 2000, 2020). Consequently, the changing demographics of Norwegian society has made Norway a more diverse nation (Brochmann \& Kjeldstadli, 2008). This has not only altered the demographic composition of pupils in Norwegian schools, it has also changed teachers' classroom work settings from homogenous to more diverse (Rosnes \& Rossland, 2018; Krulatz et al., 2018). This has accordingly had implications for teacher education, especially regarding the preparation of prospective teachers for diverse pupils in school. Thus, the growing diversity in schools demands that teachers are "able to respond 
appropriately to the variety of needs in a diverse student population" (Skrefsrud, 2016, p. 11) and that related issues are brought to the forefront of educational research (Engen et al., 2018).

In order to address the needs and challenges associated with diversity, it is imperative that preservice teachers have the knowledge, skills and attitudes required for working with pupils from diverse backgrounds. ITE should play a significant role in the process of teacher preparation for pupil diversity in school. In Norway, the ITE for compulsory school (grades 1 through 10) is nationally regulated and offered through two 4-year concurrent and integrated programmes, which qualify preservice teachers for work (Munthe et al., 2011; Thomassen \& Munthe, 2021). Starting in 2017, the ITE has been transformed into a 5-year integrated master's programme. The purpose of our study is to investigate how preservice teachers attending a 4-year ITE programme reflect on the notion of diversity and on teaching diverse pupil populations with respect to the preservice teachers' preparedness for working in diverse classroom settings in Norwegian compulsory school.

\section{Previous research on teacher preparation for diverse classrooms}

There is a large international body of empirical studies that explore preservice teachers' perspectives on diversity. Such studies have focused particularly on understanding preservice teachers' attitudes and beliefs about diversity and their experiences with diverse pupil groups (Hollins \& Guzman, 2005). Similarly, Cochran-Smith et al. (2015) point out the need for research that investigates how teacher preparation influences teacher candidates' practice, especially when navigating the "complex task of teaching increasingly diverse populations" (p. 117). Likewise, Sleeter and Owuor (2011) stress the need for more research that "follows teachers through their teacher preparation programmes" (p. 534), revealing how and to what extent ITE prepares preservice teachers for their work in diverse classroom settings. A study undertaken by Hollins and Guzman (2005), as reported in Sleeter and Owuor (2011), identifies two major themes: "[first], preservice teachers' attitudes, beliefs, predispositions and prior experiences with diverse groups, and [second, the] impact of approaches to preparing teachers for diversity" (p. 527). These themes dominate research on teacher preparation for pupil diversity. Similarly, Ross and Smith's (1992) study on preservice teachers' perspectives regarding diversity has raised important questions, such as to what extent preservice teachers' knowledge of diversity has been shaped by teacher preparation programmes and how theoretical learning influences actual teaching in diverse classrooms. The study by Siwatu et al. (2009) reveals that preservice teachers, even after having completed courses on diversity, demonstrate low selfefficacy concerning their implementation in teaching.

Cochran-Smith et al. (2008) state that despite some progress in recognising diversity-related issues as important aspects of teacher education research, discrepancies persist between the rhetoric and the reality of teacher preparation for 
pupil diversity in schools. Teacher preparation for diverse classroom settings should consider the everyday reality of classrooms to prepare prospective teachers for their work with diversified learner groups, and Korthagen (2001) states that the rhetoric and the reality of teacher preparation relates to establishing a good coherence between theory and practice in teacher education. Nevertheless, Cochran-Smith et al. (2015) state that despite many efforts to address issues of diversity in teacher education research, questions about how teacher education prepares and supports prospective teachers in their response to the needs and challenges of diversity, requires further investigation.

In Norway, previous studies on diversity primarily focused on issues related to pupils' ethnicity, language and special educational needs, as well as the processes of inclusion and exclusion in classrooms (e.g., Pihl, 2010; Kovač \& Jortveit, 2011; Jortveit, 2014; Hilt, 2017; Ohna, 2005). In addition, other studies address diversity from in-service teachers' work perspectives, namely their experience in culturally and linguistically diverse classrooms (e.g., Skrefsrud, 2016; Rosnes \& Rossland, 2018; Burner \& Biseth, 2016; Burner et al., 2018; Lund, 2018). However, there are few studies that investigate preservice teachers' perspectives on diversity in relation to their work in multicultural and multilingual classroom settings (e.g., Thomassen \& Munthe, 2021; Thomassen, 2016; Iversen, 2019). The growing heterogeneity of pupils in Norwegian schools has challenged the educational premise of a 'school for all', which demands that preservice teachers be prepared to meet the learning needs of diversified pupils in school. As a result, these changing circumstances call for more research, especially studies that investigate issues related to understanding the notion of diversity from the perspectives of preservice teachers' work in diverse classrooms.

Investigating preservice teachers' perspectives on diversity is a significantly important yet under-researched theme, particularly in the Norwegian context. Hence, we need more insight into how their conceptualisation of diversity relates to their preparedness for teaching pupils from diverse backgrounds. In this study, we aim to investigate how Norwegian preservice teachers reflect on issues of diversity and teaching in classrooms characterised by pupils from diverse backgrounds. Specifically, the study addresses the following research question:

How do preservice teachers reflect on diversity and on teaching diverse pupils in Norwegian compulsory school?

To explore this, the research question focuses on how preservice teachers consider notions of diversity and teaching pupils from diverse backgrounds, and how the dimension of theory and practice relates to preparing them for diverse classroom settings. 


\section{Theoretical framework}

\section{Diversity responsive teacher education}

The increased pupil diversity in schools has significant implications for teachers' work in classrooms, as it gives rise to challenges for teachers in creating equitable learning opportunities for all pupils regardless of their differences (Florian \& Spratt, 2013). Hence, Messiou and Ainscow (2015) state that "increasing diversity in schools means that teachers need more effective forms of professional development to address the challenges they face" (p. 246). Consequently, this demands teachers who understand diversity from multiple perspectives and are capable of teaching pupils from diverse backgrounds (Florian \& Pantić, 2017; Florian, 2009). ITE plays an important role in the process of preparing preservice teachers who possess the knowledge, skills and attitudes necessary to address the needs and challenges associated with diversity. In so doing, it is necessary to include notions of diversity as important aspects of teacher preparation for diverse pupils (Ball \& Tyson, 2011) to foster teachers' diversity-related dispositions (Leavy, 2005). It is thus important to design and implement teacher preparation programmes that address diversity (OECD, 2010; European Commission, 2017).

Villegas et al. (2017) state that the task of teaching diverse pupils needs to be understood within a larger social context by reflecting on the overall role and function of education in the creation of an equitable human society. Similarly, Florian (2012) states that teachers' responses to diversity relate to how effectively they are prepared to teach all pupils in diverse classrooms. However, the preparation of teachers capable of working with all pupils is not an easy task. In line with this, Darling-Hammond (2011) states that "it is impossible to prepare tomorrow's teachers to succeed with all of the students they will meet without exploring how both students' and teachers' learning experiences are influenced by their home languages, cultures and contexts" (p. ix). Furthermore, Gay (2018) argues that teaching becomes most effective when pupils' prior experiences, as well as cultural and other backgrounds, are included in the implementation of teaching.

\section{Conceptualising diversity}

Paine (1990) identifies four categories of conceptualising diversity, namely the individual, categorical, contextual and pedagogical. The individual orientation to diversity views differences in terms of individual characteristics that are often associated with the biological and psychological origins of individuals. This means that preservice teachers with an individual orientation tend to attribute differences within individual pupils as natural. The categorical orientation to diversity considers difference as repeating patterns of variation across individuals where the differences are perceived as influenced by pupils' categorical membership. Such categories might include pupils' language, gender, social class, race, religion, special needs and so forth. Moreover, the categorical orientation to 
diversity tends to perceive that teaching pupils with diverse backgrounds requires equal access to knowledge without challenging the societal categorisations responsible for the construction of differences. This view towards diversity considers treating everyone equally regardless of the differences among individuals.

Paine's contextual orientation to diversity builds on the first two orientations, where "differences among individuals occur in patterns, yet these patterns are seen as connected to a social situation or embedded in larger, dynamic context" (p. 3). Unlike the first two orientations, the contextual orientation views difference as socially constructed by considering the causes of the difference, which means the differences exist due to social context. The preservice teachers who hold a contextual orientation to diversity, believe that differences are "created, maintained, and changed by their interaction" (Paine, 1990, p. 3) in social settings. In comparison, the pedagogical orientation to diversity considers differences "not only in terms of causes but also in terms of implications" (Paine, 1990, p. 3), which suggests that those differences that are socially constructed have implications for teachers' educational practices in classrooms. Paine (1990) states that the pedagogical orientation "assumes that differences are not simply random and interesting; they are understood as having pedagogical implications and consequences for both teaching and learning” (p. 3). For instance, pupils' learning styles might have implications for teaching that will have consequences for their learning outcomes.

Paine's orientation towards diversity is considered a relevant and suitable framework to conceptualise broadly the differences within contexts of education and teaching (Bell et al., 2007; Gordon et al., 2010). However, research often tends to emphasise certain categorical aspects of differences, such as pupils with linguistic minority backgrounds (Gearon et al., 2009), and this tends to reduce the possibility of understanding diversity from a broader perspective (Florian \& Pantić, 2017).

In his conceptualisation of diversity in inclusive educational settings, Norwich (2008) introduces the perspective of dilemmas of difference. To elaborate notions of dilemmas, he presents three related aspects, namely identification, curriculum and location. The dilemma of identification relates to recognising or noticing differences. Similarly, the dilemma of curriculum deals with whether to provide a common curriculum for all learners, such as Paine's categorical orientation, where common knowledge is considered to suit everyone's needs. The dilemma of location is concerned with whether all learners receive the opportunity to be placed in the same educational location regardless of any additional learning needs. Having recognised these three aspects of dilemmas, preservice teachers can create equitable educational practices that are responsive to pupils' differences. Similarly, Norwich (2008) states that there is an implication regarding how differences are handled by reflecting on tensions between the rhetoric and the reality of the differences. The basic dilemma is nevertheless whether to recognise and respond to the differences explicitly by treating everyone the same or as 
distinctly different. Hence, Paine's (1990) four orientations for understanding diversity and Norwich's (2008) three aspects of dilemmas of difference provide guidelines for our discussion of the results.

\section{Methods}

\section{Research design}

The study adopts a qualitative design based on a constructivist paradigm that assumes the existence of multiple socially constructed realities (Lincoln \& Guba, 2000) and seeks to understand the phenomenon in question from the participants' perspectives (Merriam \& Tisdell, 2016). The research question is concerned with exploring the meanings and experiences of the participants, which are best examined by qualitative methods (Blaikie, 2010). In this study, we therefore choose to rely on qualitative data to explore preservice teachers' reflections on diversity and on teaching in diverse classrooms.

\section{Ethical considerations}

Ethical issues are an integral part of a qualitative design and this pertains to the entire research process (Brinkmann \& Kvale, 2015; Maxwell, 2013). As part of ethical considerations, the study was reported to the Norwegian Centre for Research Data (NSD). Moreover, informants' consent was sought, and anonymity regarding the research sites and participants was ensured. However, one of the main ethical challenges encountered in the research process was the issue associated with participant recruitment.

\section{Selection of schools and participants}

Following a strategic selection procedure, two public schools (with grades 1-7 and 5-10, respectively) located in the Western region of Norway were selected for the study. The main reason for selecting these two schools was the presence of diverse pupil populations. The demographic profile of pupils in both schools varied in terms of ethnicity, language, religious and cultural origin, socioeconomic status and intellectual and behavioural variation. Hence, the diverse profile of pupils in the selected schools provided suitable contexts for the process of empirical data construction.

In Norway, all preservice teachers are required to take a minimum of 60 study points (ECTS) in the compulsory subject Pedagogy and Pupil Knowledge (PEL). In the second year, the subject of PEL (PEL-2) includes course work on issues related to diversity in schools with the aim of developing preservice teachers' understanding and knowledge about diversity. Specifically, preservice teachers upon completion of PEL-2 should have knowledge of the following: 
the diversity related to family forms and the upbringing of children and youths and development and learning of children and young people in various social, linguistic, religious and cultural contexts, the challenges and opportunities the school faces when it comes to pupils with special needs for adapted education, of pupils with multicultural and multilingual backgrounds, and variations in gender identity and similarities and differences in boys' and girls' conditions. (Ministry of Education \& Research, 2010, p. 18)

The participants in this study comprised preservice teachers enrolled in a 4-year ITE programme. Following a strategic selection procedure, those preservice teachers attending the third and the fourth year of an ITE programme (for either grades $1-7$ or grades $5-10$ ) were invited to participate in the study. The reason for including preservice teachers from the third and the fourth year was to include only those preservice teachers who had completed the PEL-2 course. The recruitment of participants was completed via a two-step process. First, the project was presented to preservice teachers preparing for their field placement in the selected schools. From each of the year-groups, one group of preservice teachers responded positively to participating in the study. Second, each participant provided a written consent to confirm their participation. Each of the two groups consisted of four participants in the age range 22-27 years, altogether seven females and one male.

\section{Data construction and analysis}

\section{Focus group interviews}

The focus group interview is an approach that emphasises interaction within groups for joint construction of meaning on a particular research topic or theme to explore a variety of viewpoints from the participants (Bryman, 2012; Brinkmann \& Kvale, 2015). Since this study aims at exploring preservice teachers' perspectives on diversity and on teaching in diverse classrooms, focus group interviews were considered a suitable method for data construction. Unlike individual interviews, focus group interviews make it possible to investigate how participants "respond to each other's views and build up a view out of the interaction that takes place within the group" (Bryman, 2012, p. 501) through a dynamic group interaction among the participants (Stewart \& Shamdasani, 2015).

To conduct the focus group interviews, an interview guide centred on preservice teachers' views on diversity and how they reflect on teaching diverse pupils, was used. The researcher (first author) took a moderator's role and introduced themes for the focus groups. The focus group interviews lasted about sixty minutes and were audio-recorded with consent from the participants. The focus group interviews were completed in autumn 2017 and spring 2018 after the preservice teachers had completed their two-week long field placement. 


\section{Data analysis}

A thematic analysis (Braun \& Clarke, 2006) was adopted to analyse the focus group interviews, which included the following steps. The first involved listening to and transcribing the audio-recorded interviews. The verbatim transcription of the interviews was done partly by the first author and partly by an external professional transcriber. Later, both authors were involved in reading and analysing the transcriptions. Secondly, the contents of the transcriptions were coded following a manual coding method (Saldaña, 2010; Basit, 2003) that used a highlighter and post-it-notes technique. Several codes were employed, such as 'familiarity', 'everyone different', 'space for all', 'adapted teaching', 'cultural difference', 'background knowledge', 'short practice', and 'theory-practice tension'. For example, the codes 'everyone different', 'familiarity' and 'need variation' were employed for the following data extract: "All pupils are different, and they have different needs. [...] there are also things you might experience a little more when you get to know the pupils."

In the third step, the codes were grouped together based on their semantic homogeneity to develop initial themes. In order to house the content of the codes, the following four themes were developed: 'individuality', 'values', 'theorypractice dimension', and 'miscellaneous'. In the fourth phase of the analysis, the initial themes were inspected in terms of their internal homogeneity and external heterogeneity across the codes, as well as the entire data corpus, to ensure that no data relevant to the research question was omitted. The content of the codes can thus largely be related to the identified themes. However, the content housed under 'miscellaneous' was identified as irrelevant and therefore excluded, which means only the first three themes were considered relevant to the research question. As a result, only the concepts of individuality and inclusive teaching, differences as resource, and theory-practice dynamics were considered necessary and relevant to the study's aim and research question. Finally, the initial inspection resulted in three main themes that were considered relevant to the research question, and they are defined as presented in the results section below. Examples of data excerpts are included in the presentation of the results to augment the transparency and trustworthiness of the results. The aspects of reflexivity and respondent validation (Maxwell, 2013) have been taken into consideration in the construction and analysis of data to address issues of validity and reliability concerning the results.

\section{Results}

In this section, the results are presented and discussed. The three main results from the analysis are as follows: (1) differences are individual and considered natural, (2) diversity as a value and challenge, and (3) belief in practice rather than theory. 


\section{Difference is individualistic and considered natural}

While discussing both diversity and teaching in diverse classrooms, the preservice teachers demonstrated their awareness and appreciation of diversity. They mentioned that every pupil is different and that differences are natural. Reflecting on these differences in focus group interviews, one of the participants said, "[...] all pupils are different and they have different needs". The other participants in the groups also added that every pupil is different and has different educational needs that must be addressed. Additionally, they emphasised the importance of becoming familiar with pupils' family and other background factors, as knowing that this is significant for the implementation of diversity sensitive teaching. One of the participants said, "it's very nice to be aware of sort of background experience with, or background knowledge about the pupil before you go to a classroom". Other participants mentioned that by being familiar with pupils' backgrounds, it is possible to create learning conditions that are suitable for meeting the diverse educational needs of all pupils.

Likewise, the preservice teachers pointed to the significance of adapted teaching, where pupils' prior learning experiences and other background factors are considered as significant factors in the process of planning and implementing teaching. One of the participants said, "I also think a bit about [... that] all pupils are different and then I also think a lot about adapting educational practices, facilitating learning for all the pupils”. Other participants agreed on the importance of adapted educational practices in order to facilitate learning for everyone in the classroom. In addition, they highlighted the significance of including the differences while planning and implementing teaching, and further stated that through the implementation of adapted teaching it becomes possible to address pupils' differences. They also mentioned that the implementation of inclusive teaching is one way to address the diversity.

Reflecting on diversity, one of the participants said, "[...] there is a lot of diversity at this school, but I haven't really noticed it”. Other participants agreed with this statement and added that it is natural to have pupils from various backgrounds. They categorised diversity in terms of the individual and group characteristics of pupils, such as language, culture, ethnicity and special educational needs. This sort of framing of diversity relates to an individual and group orientation towards diversity. They also emphasised the significance of having knowledge of and being familiar with pupils' family and other backgrounds, which relates to a contextual and pedagogical orientation towards understanding diversity. Although they demonstrated a positive view towards diversity, they were uncertain of what to do with it, which shows their dilemma of differences. Such dilemmatic views towards diversity raise an interestingly important question regarding how diversity is conceptualised and dealt with in relation to whether everyone is to be treated the 'same' or 'different'. 


\section{Diversity as a value and a challenge}

In the focus group interviews, the preservice teachers discussed the different forms of diversity prevalent in classrooms. They categorised diversity as related to special educational and behavioural needs, low socio-economic status, different ethnicities, particular cultural and religious origins and Norwegian as a second or foreign language. They considered these various forms of diversity as a positive value. One of the participants said, "[...] you often talk about the individual pupils who often have a special challenge or need, [and] you often talk about those challenges and needs, you probably don't talk much about the advantages of diversity”. The value perspective of diversity considers difference as a positive resource. This means that the differences pupils bring to the classroom are used as resources for one another. Thus, the value perspective of diversity appreciates commonalities shared by individuals and groups, where the differences are considered something positive.

Hence, this advocates that differences should be acknowledged and valued. By valuing differences, the preservice teachers not only acknowledge them, they also create an inclusive learning environment for everyone. Describing pupil diversity as a positive resource, one of the participants said, "[...] in the books [curriculum and textbooks] as such, there is a lot about how you can use them [pupils] as a resource in the classroom". The preservice teachers considered diversity as something positive to be utilised for pupils' learning. Confirming this, one of the participants said, "there [in the classrooms] they [pupils] should learn from each other [and] use one another as resources". Through their discussions about diversity as a value, the preservice teachers emphasised the importance of drawing connections to pupils' prior experiences and other backgrounds while planning and implementing teaching. Thus, the value perspective on diversity considers differences as a positive resource to be utilised in teaching pupils from diverse backgrounds.

In contrast, the preservice teachers also discussed the challenges that diversity can create. Reflecting on any challenges associated with diversity, one of the participants said:

\footnotetext{
I think we had a lot of good discussions in teacher education about diversity and have learned about many sides of it, many different pupils and how you should accommodate them. During our teacher education we have gone through much [...] in the different types of groups, but we have not received very much information about what we should do in a way, the didactics, how we should adapt the sort of teaching. To be honest, we have only received information about their characteristics.
}

The preservice teachers mentioned challenges associated with how diversity can be used as a resource. They stated that even teachers who have spent many years working with diverse pupils might face difficulties in handling diversity. This shows preservice teachers' uncertainties concerning how to address differences while teaching diverse pupil groups. For example, they mentioned that diversity 
cannot just be taken as something good without thinking of the challenges associated with it.

Reflecting on their experiences from teaching in schools, the preservice teachers pointed out how identifying some pupils as 'challenging' can be problematic when it comes to working with diversity. One of the participants said, "[...] perhaps in relation to my own experiences as such, on the negative [challenge] side that is in a way all of these diagnoses that are to be found in the pupils that are then problematic in the school”. The other participants added that the task of getting along with everyone is one of the most challenging aspects of working with diverse pupils. It is also essentially important that the variety of learning needs represented by diverse pupils are taken into account. Despite their appreciative views towards diversity, the preservice teachers also reflected on challenges associated with diversity. Hence, the preservice teachers seem to hold positions regarding diversity both as something to be valued as well as challenge.

\section{Belief in practice rather than theory}

The preservice teachers in the focus group interviews reflected on their experiences of learning about issues related to diversity through teacher preparation programmes. They discussed discrepancies between theory and practice in ITE, where they pointed to the significance of theoretical knowledge as a necessary part of teacher preparation. They moreover emphasised the need for more opportunities to practise their skills rather than just focus on theoretical learning. One of the participants said:

Yes, so we must know the theory just like that, that's the goal, that's how it should be, blah, blah, blah. And then more practical experience. I completely agree with what you are saying in theory. It's crazy difficult to do that in practice. Well, the theory is good to have in a way in the back of your head, but we don't need so much.

Similarly, when reflecting on the dimension of theory-practice coherence, one of the participants added, "we need to have practice where the focus is diversity and not to develop ourselves [just] as classroom leaders". The preservice teachers stated that one of the aspects related to theory-practice coherence concerns the inclusion of more practical examples and case studies on issues related to diversity in schools. By highlighting the inconsistency between theoretical learning and its practical implications for teaching, one participant said, "they're very good at talking about [...] diversity here and there and that it's like such and such, but there's actually very little we in a way focus on when we plan lessons and such". The participants agreed on the importance of having consistency between theory and practice, where they emphasised the need for a longer field placement. One of the participants gave an example from the nursing profession and said, "take nurses, for example. One third of their education is practice. [....] why is this not so for teachers? Because teaching is an equally important profession”. Further, 
the participants added that just two to three weeks of field placement a semester does not provide sufficient opportunity to put the theory into practice.

The preservice teachers discussed coherence between theory and practice in ITE. Establishing a good coherence between theory and practice is one of the most significant aspects of teacher preparation for diverse classrooms. One of the participants said:

[....] many of my friends taking teacher education courses learned one thing on the course about what it is like being a teacher, and then they went out into practice and then it is completely different. You can't learn to be a teacher by reading a book, you know.

The participants stated that, although diversity is a discussed phenomenon in ITE, there is actually little focus on it during field placement in schools, which points to a lack of coherence between theory and practice. The preservice teachers highlighted two main aspects regarding the theory-practice dimension. One of these relates to the need for a longer field placement, whereas the second aspect concerns establishing consistency between theoretical teaching in ITE and its implications for real teaching in schools. ITE should play an important role in the process of teacher preparation for diverse classrooms. In so doing, it is important for preservice teachers to find a good connection between the theoretical knowledge gained through teacher preparation programmes and its implications for actual teaching in schools.

\section{Discussion}

The aim of this study is to explore preservice teachers' reflections on diversity and on teaching pupils from diverse backgrounds with regard to the preservice teachers' preparedness for working in diverse classroom settings.

The increased pupil diversity in schools demands that preservice teachers be educated with the knowledge, skills and attitudes needed to meet the needs and challenges associated with diversity. Hence, the goal of teacher preparation for diverse classrooms is to prepare teachers who can meet the pupils' variety of needs regardless of their differences. It is thus significant to understand how the notion of diversity is conceptualised in contexts of teacher preparation for diverse pupils and how the dimension of theory-practice relates to the process of preparing preservice teachers for teaching pupils from diverse backgrounds.

\section{Teacher preparation for diverse pupil populations}

One of the results from the study relates to preservice teachers' conceptualisation of diversity. This result indicates that the differences are individual and considered natural. Understanding diversity as an individualistic and natural phenomenon relates to Paine's (1990) perspective on conceptualising diversity, 
where the differences are viewed in terms of pupils' individual characteristics. Likewise, the results point to the significance of including pupils' personal, family and other backgrounds in teaching. By so doing, it becomes possible for teachers to include everyone. Such views towards diversity relate to it as a value perspective, where the differences are considered a positive resource for all pupils in the classroom. In addition, the results point to the significance of becoming familiar with pupils' prior learning, life experiences and other contextual backgrounds. This is in line with Gay's (2018) statement: "teaching is most effective when ecological factors, such as prior experiences, community settings, cultural backgrounds and ethnic identities of teachers and students, are included in its implementation" (p. 28). This means that teaching diverse pupils becomes more meaningful when personal and other factors are reflected in their learning. Villegas and Lucas (2002) state that when teachers include pupils' personal, family and other information in teaching, their differences are acknowledged and embraced, that is, the differences that the pupils bring into classrooms are recognised and valued.

However, at the same time, various contextual factors, like pupils' social class, language, culture and similar factors, are considered influential factors for learning. Paine (1990) states that categorical and contextual variations of diversity are responsible for creating patterns of differences among pupils, and these need to be recognised and provided a response. Thus, the task of teaching diverse pupils requires that they take into account individual, categorical, contextual and pedagogical aspects of pupils' differences. In the same way, Norwich (2008) points out that the process of working with diversity relates to dilemmas of identification, curriculum and location. The dilemma of identification concerns recognising and valuing the differences, whereas the curriculum refers to whether everyone should be treated equally and offered a common learning content. Location deals with whether every pupil is placed within the same classroom despite their differences. The dilemmatic perspectives of diversity raise interesting and important concerns regarding preservice teachers' conceptualisation of diversity and teaching pupils from diverse backgrounds.

Paine's (1990) perspectives on understanding diversity allow us to conceptualise diversity in a broader perspective by providing an implied hierarchical path. For instance, preservice teachers might start by becoming familiar with pupils' individual and other contextual backgrounds prior to planning lessons for teaching. However, shifting from one perspective to another will have consequences for preservice teachers' pedagogical actions. Therefore, critics of Paine's framework for understanding diversity, such as Bell et al. (2007), state that it does not specify how "teachers might move from one kind of understanding to another" (p. 125).

The results in this study indicate that individual and categorical perspectives are more prevalent in preservice teachers' conceptualisation of diversity, which means that they did not point out the consequences of contextual perspectives in 
the implementation of pedagogical activities. Thus, it is imperative that preservice teachers consider all four dimensions of diversity in order to provide a broader frame for their conceptualisation of diversity and teaching of pupils from diverse backgrounds. Similarly, the results indicate that the preservice teachers are aware of pupil diversity and have positive views towards it. Nevertheless, they are uncertain regarding whether they should treat everyone as the 'same' or 'different' when it comes to recognising and responding to differences. As a result, the preservice teachers' dilemma of difference has implications for teaching pupils from diverse backgrounds. Since such differences, according to Paine (1990), are created in larger social contexts, they have pedagogical implications for teachers' work in diverse classroom settings.

The results from the study also reveal a lack of coherence between preservice teachers' theoretical learning at ITE and its implications for teaching in schools. This corresponds to the findings of Siwatu et al. (2009). The dimension of theorypractice coherence is one of the key issues in teacher education for diversity. This points to the significance of having good coherence between the 'rhetoric' and 'reality' of teacher preparation for diverse classrooms. Schjetne and Skrefsrud (2018) thus emphasise that, in the changing circumstances of growing pupil diversity in schools, it is essential that teachers are well prepared for teaching all pupils regardless of their differences. Therefore, Florian and Pantić (2017) state that the task of preparing teachers for diverse classrooms demands that preservice teachers be educated to view diversity from a broader perspective and have a coherent conception of theory and practice in teacher education.

Dack (2019) states that the process of preparing teachers for diverse classrooms involves developing teacher candidates' knowledge, skills and dispositions through course work and field placement. Feiman-Nemser (1983) points out that teachers' learning involves not only what teachers are taught, but also how they are taught. It is therefore important that the teacher candidates' practical experiences from schools should be linked to their learning settings in teacher preparation programmes (Klette et al., 2017). Likewise, Ross and Smith (1992) point out the significance of having consistency between preservice teachers' theoretical learning experiences from teacher education programmes and field placement in schools. On the other hand, Weston and Henderson (2015) argue that a lack of coherence between teacher candidates' course work and field placement is one of the challenges that should be addressed. It is significantly important that there is a good integration between theoretical course work and practice. That means there should be a coherent linkage between teacher candidates' theoretical knowledge and their practice in the workplace (Korthagen, 2010; Rasmussen \& RashChristensen, 2015; Smeby \& Heggen, 2014). Hence, Korthagen (2001) emphasises the significance of having coherence between teacher candidates' theoretical learning and practice in schools.

As schools continue to welcome pupils from diverse backgrounds, it is imperative that preservice teachers are prepared with the knowledge, skills and 
attitudes required to address the needs and challenges they will face in diverse classrooms. Hence, the task of preparing preservice teachers for increasingly diverse pupil populations in schools involves establishing a good coherence between theory and practice.

\section{Concluding remarks}

Drawing on qualitative data from focus group interviews, this study has explored preservice teachers' perspectives on diversity and on teaching pupils from diverse backgrounds. The study has contributed to knowledge on how preservice teachers conceptualise diversity regarding their preparedness for teaching diverse pupils. The three results differences are individual and considered natural, diversity as a value and challenge, and belief in practice rather than theory raise concerns surrounding the significance of preparing preservice teachers for a greater diversity of pupils in schools. One of the key issues in the study relates to the preservice teachers' dilemmas of diversity. Despite their positive views towards diversity, the preservice teachers therefore seem to be in a dilemmatic position regarding whether they should treat all pupils the same or differently. Moreover, the study points to the significance of coherence between theory and practice in ITE regarding the preparation of preservice teachers for diverse pupils.

The results from this study are important for understanding preservice teachers' perspectives on diversity and on teaching pupils from diverse backgrounds. However, they should be considered within the following limitations. First, the study represents a case from one form of ITE programme in a Norwegian context, while there are different structural provisions of ITE internationally. Thus, the results drawn from one qualitative investigation may not be generalisable to other settings. Second, empirical data in the study came only from focus group interviews. Perhaps the results would provide different perspectives if the views of individual participants were in focus. Third, the study did not include the perspectives of teacher educators, who are significant agents in the process of educating preservice teachers.

Initial teacher education for compulsory school in Norway is now provided through a 5-year integrated master's programme. Given the changing circumstances, it will be interesting and important for future research to investigate how issues related to diversity are framed within the 5-year master's programme in relation to the preparation of preservice teachers for increasingly diverse pupil populations in schools, including the perspectives of teacher candidates as well as teacher educators. 


\section{About the authors}

Bhupendra Kumar KC is a PhD Research Fellow in Educational Sciences at the University of Stavanger. His research interests include research on teacher education, teaching and learning, critical pedagogy, diversity, equity and social justice in education.

Institutional affiliation: Department of Education and Sports Science, University of Stavanger, N-4036 Stavanger, Norway.

E-mail: bhupendra.k.kc@uis.no

Stein Erik Ohna is a professor of Special Education at the University of Stavanger. His research interests concern issues regarding inclusive education with a special focus on conditions for participation in preschool, primary as well as secondary education.

Institutional affiliation: Department of Education and Sports Science, University of Stavanger, N-4036 Stavanger, Norway.

E-mail: stein.e.ohna@uis.no

\section{References}

Ball, A. F., \& Tyson, C. A. (2011). Preparing teachers for diversity in the twenty-first century. In A. F. Ball \& C. A. Tyson (Eds.), Studying diversity in teacher Education (pp. 399416). Rowman \& Littlefield.

Banks, J. A. (2008). An Introduction to Multicultural Education. Pearson.

Banks, J. A. (Ed.) (2012). Encyclopedia of Diversity in Education. Sage.

Basit, T. (2003). Manual or electronic? The role of coding in qualitative data analysis. Educational Research, 45(2), 143-154. https://doi.org/10.1080/0013188032000133548

Bell, C. A., Horn, B. R., \& Roxas, K. C. (2007). We know it's service, but what are they learning? Preservice teachers' understandings of diversity. Equity \& Excellence in Education, 40(2), 123-133. https://doi.org/10.1080/10665680701218467

Biesta, G. J. (2006). Beyond learning: democratic education for a human future. Paradigm.

Blaikie, N. (2010). Designing social research: The logic of anticipation. Polity Press.

Braun, V., \& Clarke, V. (2006). Using thematic analysis in psychology. Qualitative Research in Psychology, 3(2), 77-101. https://doi.org/10.1191/1478088706qp063oa

Brinkmann, S., \& Kvale, S. (2015). Interviews: Learning the craft of qualitative research interviewing. Sage.

Brochmann, G., \& Kjeldstadli, K. (2008). A history of immigration: The case of Norway 900-2000. Universitetsforlaget.

Bryman, A. (2012). Social research methods. Oxford University Press.

Burner, T., \& Biseth, H. (2016). A critical analysis of an innovative approach: A case of diversity in Norwegian education. Sage Open, 6(4). https://doi.org/10.1177/2158244016680689

Burner, T., Nodeland, T. S., \& Aamaas, Å. (2018). Critical perspectives on perceptions and practices of diversity in education. Nordic Journal of Comparative and International Education, 2(1), 3-15. https://doi.org/10.7577/njcie.2188 
Cochran-Smith, M., Feiman-Nemser, S., \& McIntyre, D. J. (Eds.) (2008). Handbook of research on teacher education: Enduring questions in changing contexts. Routledge.

Cochran-Smith, M., Villegas, A. M., Abrams, L., Chavez-Moreno, L., Mills, T., \& Stern, R. (2015). Critiquing teacher preparation research: An overview of the field, Part II. Journal of Teacher Education, 66(2),109-121. https://doi.org/10.1177/0022487114558268

Dack, H. (2019). The role of teacher preparation program coherence in supporting candidate appropriation of the pedagogical tools of differentiated instruction. Teaching and Teacher Education, 78, 125-140. https://doi.org/10.1016/j.tate.2018.11.011

Darling-Hammond, L. (2011). Foreword. In A. F. Ball \& C. A. Tyson (Eds.), Studying diversity in teacher Education (pp. ix-x). Rowman \& Littlefield.

Engen, T. O., Kulbrandstad, L. I., Kulbrandstad, L. A., \& Lied, S. (2018). Education and diversity: Introduction of a multidisciplinary research group. In L. A. Kulbrandstad, T. O. Engen, \& S. Lied (Eds.), Norwegian perspectives of education and cultural diversity (pp. 2-37). Cambridge Scholars Publishing.

European Commission (2017). Preparing Teachers for Diversity: The Role of Initial Teacher Education. Publications Office of the European Union. Available from: https://op.europa.eu/en/publication-detail/-/publication/b347bf7d-1db1-11e7-aeb301aa75ed71a1/language-en

Feiman-Nemser, S. (1983). Learning to teach. In L. S. Shulman \& G. Sykes (Eds.), Handbook of Teaching and Policy (pp. 150-170). Longman.

Florian, L. (2009). Preparing teachers to work in 'schools for all'. Teaching and Teacher Education, 25(4), 533-534. https://doi.org/10.1016/j.tate.2009.02.004

Florian, L. (2012). Teacher education for inclusion: A research agenda for the future. In C. Forlin (Ed.), Future Directions for Inclusive teacher Education: An international perspective (pp. 212-220). Routledge.

Florian, L., \& Pantić, N. (2017). Teacher education for changing demographics of schooling: Pathways for future research. In L. Florian \& N. Pantić (Eds.), Teacher education for the changing demographics of schooling: Issues for research and practice (pp. 229-236). Springer.

Florian, L., \& Spratt, J. (2013). Enacting inclusion: a framework for interrogating inclusive practice. European Journal of Special Needs Education, 28(2), 119-135. https://doi.org/10.1080/08856257.2013.778111

Florian, L., Young, K., \& Rouse, M. (2010). Preparing teachers for inclusive and diverse educational environments: studying curricular reform in an initial teacher education course. International Journal of Inclusive Education, 14(7), 709-722. https://doi.org/10.1080/13603111003778536

Gay, G. (2018). Culturally Responsive Teaching: Theory, research, and practice. Teachers College Press.

Gearon, M., Miller, J., \& Kostogriz, A. (2009). The challenges of diversity in language education. In J. Miller, A. Kostogriz, \& M. Gearon (Eds.), Culturally and linguistically diverse classrooms: New dilemmas for teachers (pp. 3-17). Multilingual Matters.

Gordon, S., Reid, A., \& Petocz, P. (2010). Educators' conceptions of student diversity in their classes. Studies in Higher Education, 35(8), 961-974. https://doi.org/10.1080/03075070903414305

Hilt, L. T. (2017). Education without a shared language: dynamics of inclusion and exclusion in Norwegian introductory classes for newly arrived minority language students. International Journal of Inclusive Education, 21(6), 585-601. https://doi.org/10.1080/13603116.2016.1223179 
Hollins, E., \& Guzman, M. T. (2005). Research on preparing teachers for diverse populations. In M. Cochran-Smith \& K. Zeichner (Eds.), Studying teacher education: The report of the AERA panel on research and teacher education (pp. 477-548). Lawrence Erlbaum.

Humphrey, N., Bartolo, P., Ale, P., Calleja, C., Hofsaess, T., Janikova, V., Mol Lous, A., Vilkiene, V., \& Wetso, G.-M. (2006). Understanding and responding to diversity in the primary classroom: an international study. European Journal of Teacher Education, 29(3), 305-318. https://doi.org/10.1080/02619760600795122

Iversen, J. Y. (2019). Negotiating language ideologies: preservice teachers' perspectives on multilingual practices in mainstream education. International Journal of Multilingualism. https://doi.org/10.1080/14790718.2019.1612903

Jortveit, M. (2014). Inkludering i en flerkulturell skole: En kvalitativ studie av forståelsen av inkludering uttrykt i styringsdokumenter og blant læerere [Inclusion in a multicultural school: A qualitative study of the understanding of inclusion expressed in policy documents and among teachers]. Doctoral dissertation, University of Agder, Norway. http://hdl.handle.net/11250/281941

Klette, K., Hammerness, K., \& Jenset, I. S. (2017). Established and evolving ways of linking to practice in teacher education: Findings from an international study of the enactment of practice in teacher education. Acta Didactica Norge, 11(3), Art. 9. http://dx.doi.org/10.5617/adno.4730

Koppelman, K. (2011). The great diversity debate: Embracing pluralism in school and society. Teachers College Press.

Korthagen, F. A. J. (2001). Linking practice and theory: The pedagogy of realistic teacher education. Lawrence Erlbaum.

Korthagen, F. A. J. (2010). The relationship between theory and practice in teacher education. In P. Peterson, E. Baker, \& B. McGaw (Eds.), International Encyclopedia of Education, 7 (pp. 669-675). Elsevier.

Kovač, V. B., \& Jortveit, M. (2011). The 'why, what and how' of inclusion from the practitioner's point of view: Inclusion of immigrant children in the Norwegian educational system. Power and Education, 3(3), 289-303. https://doi.org/10.2304/power.2011.3.3.289

Krulatz, A., Steen-Olsen, T., \& Torgersen, E. (2018). Towards critical cultural and linguistic awareness in language classrooms in Norway: Fostering respect for diversity through identity texts. Language Teaching Research, 22(5), 552-569.

https://doi.org/10.1177/1362168817718572

Leavy, A. (2005). 'When I meet them, I talk to them': The challenges of diversity for preservice teacher education. Irish Educational Studies, 24(2-3), 159-177. https://doi.org/10.1080/03323310500435422

Lincoln, Y. S., \& Guba, E. G. (2000). Paradigmatic controversies, contradictions, and emerging confluences. In N. K. Denzin \& Y. S. Lincoln. (Eds.), Handbook of qualitative research (pp. 163-188). Sage.

Lund, A. B. (2018). En studie av læreres forståelse av mangfoldsbegrepet [A study of teachers' understanding of the concept of diversity]. Nordisk tidsskrift for pedagogikk og kritikk, 4, 87-102. https://doi.org/10.23865/ntpk.v4.608

Maxwell, J. A. (2013). Qualitative Research Design: An Interactive Approach. Sage.

Merriam, S. B., \& Tisdell, E. J. (2016). Qualitative research: A guide to design and implementation. Jossey-Bass.

Messiou, K., \& Ainscow, M. (2015). Responding to learner diversity: Student views as a catalyst for powerful teacher development? Teaching and Teacher Education, 51, 246-255. https://doi.org/10.1016/j.tate.2015.07.002 
Ministry of Education and Research (2010). Nasjonale retningslinjer for grunnskolelererutdanningen 1.-7. trinn [National guidelines for primary school teacher education, grades 1-7].

https://www.regjeringen.no/globalassets/upload/kd/rundskriv/2010/retningslinjer_grunnsk olelaererutdanningen_1_7 trinn.pdf

Munthe, E., Malmo, K.-A. S., \& Rogne, M. (2011). Teacher education reform and challenges in Norway. Journal of Education for teaching: International research and pedagogy, 37(4), 441-450. https://doi.org/10.1080/02607476.2011.611012

Norwich, B. (2008). Dilemmas of difference, inclusion and disability: International perspectives and future directions. Routledge.

OECD (2010). Educating Teachers for Diversity: Meeting the Challenge. Educational Research and Innovation. OECD Publishing. https://www.oecd.org/education/ceri/educatingteachersfordiversitymeetingthechallenge.ht $\underline{\mathrm{m}}$

Ohna, S. E. (2005). Researching classroom processes of inclusion and exclusion. European Journal of Special Needs Education, 20(2), 167-178. https://doi.org/10.1080/08856250500055651

Paine, L. (1990). Orientations toward diversity: What do prospective teachers bring? National Centre for Research on Teacher Education.

Pihl, J. (2010). Etnisk mangfold i skolen: Det sakkyndige blikket [Ethnic diversity in school: The expert gaze]. Universitetsforlaget.

Rasmussen, J., \& Rash-Christensen, A. (2015). How to improve the relationship between theory and practice in teacher education. Educational Research for Policy and Practice, 14, 213-230. https://doi.org/10.1007/s10671-015-9180-5

Rosnes, E. V., \& Rossland, B. L. (2018). Interculturally competent teachers in the diverse Norwegian educational setting. Multicultural Education Review, 10(4), 274-291. https://doi.org/10.1080/2005615X.2018.1532223

Ross, D. D., \& Smith, W. (1992). Understanding preservice teachers' perspectives on diversity. Journal of Teacher Education, 43(2), 94-103. https://doi.org/10.1177/0022487192043002003

Saldaña, J. (2010). The coding manual for qualitative researchers. Sage.

Schjetne, E., \& Skrefsrud, T.-A. (2018). Mangfoldig skole - bred kompetanse [Diverse school - broader competence]. I E. Schjetne \& T.-A. Skrefsrud (Eds.), A være lærer i en mangfoldig skole: Kulturelt og religiøst mangfold, profesjonsverdier og verdigrunnlag [Being teacher in a diverse school: Cultural and religious diversity, professional values and norms] (pp. 11-20). Gyldendal.

Siwatu, K. O., Polydore, C. L., \& Starker, T. V. (2009). Prospective elementary school teachers' culturally responsive teaching self-efficacy beliefs. Multicultural Learning and Teaching, 4(1), Art. 2. https://doi.org/10.2202/2161-2412.1040

Skrefsrud, T.-A. (2016). The intercultural dialogue: Preparing teachers for diversity. Waxmann.

Sleeter, C. E., \& Owuor, J. (2011). Research on the impact of teacher preparation to teach diverse students: The research we have and the research we need. Action in Teacher Education, 33(5-6), 524-536. http://dx.doi.org/10.1080/01626620.2011.627045

Smeby, J.-C., \& Heggen, K. (2014). Coherence and the development of professional knowledge and skills. Journal of Education and Work, 27(1), 71-91. https://doi.org/10.1080/13639080.2012.718749

Statistics Norway (2000). Immigrants and Norwegian-born to immigrant parents. https://www.ssb.no/en/befolkning/statistikker/innvbef/arkiv/2000-11-13 
Statistics Norway (2020). Immigrants and Norwegian-born to immigrant parents. https://www.ssb.no/en/innvbef

Stewart, D. W., \& Shamdasani, P. N. (2015). Focus Groups: Theory and Practice. Sage.

Thomassen, W. E. (2016). Lærerstudenters kommentatorkompetanse om flerkultur og undervisning av flerspråklige elever drøftet i lys av kritisk multikulturalisme [Preservice teachers' commentary competence on multiculturalism and teaching of multilingual pupils discussed in the light of critical multiculturalism]. Acta Didactica Norge, 10(1) Art. 2. https://doi.org/10.5617/adno.2340

Thomassen, W., \& Munthe, E. (2021). Educating Norwegian preservice teachers for the multicultural classroom - What knowledge do student teachers and mentor teachers express? European Journal of Teacher Education, 44(2), 234-248. https://doi.org/10.1080/02619768.2020.1758661

Tyson, C. A., \& Ball, A. F. (2011). Introduction and overview. In A. F. Ball \& C. A. Tyson (Eds.), Studying Diversity in Teacher Education (pp. 1-15). Rowman \& Littlefield.

Villegas, A. M., Ciotoli, F., \& Lucas, T. (2017). A framework for preparing teachers for classrooms that are inclusive of all students. In L. Florian \& N. Pantić (Eds.), Teacher education for the changing demographics of schooling: Issues for research and practice (pp. 133-148). Springer.

Villegas, A. M., \& Lucas, T. (2002). Educating culturally responsive teachers: A coherent approach. State University of New York Press.

Weston, T. L., \& Henderson, S. C. (2015). Coherent experiences: The new missing paradigm in teacher education. The Educational Forum, 79(3), 321-335.

https://doi.org/10.1080/00131725.2015.1037514 